\title{
A GENERIC REVISION OF AMERICAN MOTHS OF THE FAMILY CECOPHORIDA, WITH DESCRIPTIONS OF NEW SPECIES.
}

\author{
By August Busck, \\ of the U. S. Department of Agriculture.
}

The family Ecophoridæ comprises a well-defined natural group of Tineid moths, which may be recognized by the following characters: Head normally smooth, with appressed scales, sometimes with loose scales and spreading side tufts. Antennæ normally with pecten on basal joint, though in some genera without. Labial palpi well developed, generally curved upward; terminal joint acutely pointed. Maxillary palpi obsolete or very small, simple, appressed. Forewings normally with 12 veins (sometimes 11 by coincidence); veins 7 and $S$ stalked (or rarely coincident); 7 to costa or termen; veins 2 and 10 from before the angles of the cell; $1^{b}$ furcate at base. Hindwings with 8 veins (or rarely with only 7 , through coincidence); veins 6 and 7 remote, parallel; 3 and 4 normally connate or stalked (though in a few genera separate and in one genus coincident); 8 free. Posterior tibiæ clothed with rough hairs above.

These characters suffice to distinguish the family from all other Microlepidoptera except the allied family Blastobasidæ and a few genera of the Gelechiidæ, which partake of most or all of them.

These Gelechiidæ are, however, readily distinguished by the sinuate hindwings, and the Blastobasidæ are easily separated by the following differences: The very long cell in the forewing, as compared with the lengths of the apical veins and the massing of these veins $(2-10)$ at the end of the cell, which, together with the subbasal origin of vein 11 , causes veins 10 and 11 to be unusually distant. To make up for the resulting weakening of the wing, the membrane is more or less thickened along the costa (the "stigma" of Zeller). Another character, in which the Blastobasidæ normally differ from the Ecophoridæ, is the proximity or coincidence of veins 3,4 , and 5 in the hindwing, but this is approached or equaled in certain Ecophorid genera (as Triclonella). 
The peculiar secondary sexual characters of the antennæ I consider of no generic value, and as they are found only in about half the forms undoubtedly related to Blastobasis, they afford no help in the family separation except in so far that they are not known to occur in the family Ccophoridæ.

The family Ecophoridæ is represented rather numerously in all faunal regions, though predominant only in Australia. Several of the genera and a few species are cosmopolitan.

Very little special study has hitherto been given the North American species of this family, and the existing lists need considerable revision. Our fauna is closely related to the European, and most of the genera (though only very few species) are common to both continents.

In Doctor Dyar's List of North American Lepidoptera 92 species are recorded in this family, of which I find six do not belong here and have been disposed of in the following under the genera in which they are placed in Dyar's List. Since the publication of that list 29 species have been described and three species before regarded as synonyms have been recognized as valid; two species have been transferred to this family from elsewhere, and five new species are now described, making our list in this family number 121 species. All but half a dozen of these are represented in U. S. National Museum collection, and only two species are known to the writer by description alone. The types of all new species described in the present paper are deposited in the U. S. National Museum.

Thirteen genera are recorded in Dyar's List; one of these (Chambersia Riley) can hardly be included in this family from the description, and one was erroneously credited to our fauna. On the other hand, three genera have been transferred to this family from elsewhere; one good American genus has been resurrected from the synonymy, one European genus has been recognized from California, and four new genera are erected in the following, making a total of 21 genera of this family at present recognized in North America. Of these, nine are cosmopolitan or nearly so, two are common to Europe and America, and nine have as yet not been recognized outside of America.

The larvæ of the Ccophoridæ have very various life modes, though the majority live either in spun leaves or feed in decayed wood; one American genus is parasitic on Kermes. The larvæ are often prettily marked with dark tubercles on whitish or yellowish ground; they have six true legs and ten prolegs. The pupæ have segments 9-11 movable and do not protrude from the cocoon when the imago emerges.

A few of the species are of some economic importance as enemies of cultivated crops. Many of the species overwinter as adults in 
thatch or under bark or, as in the case of some Depressaria, in houses, thereby occasionally causing unnecessary alarm when they appear in numbers at the approach of warm weather.

Several additional undescribed species are represented in the National Museum and very many species of the family will yet be discovered when the fauna is better worked up.

The writer had intended to make the present paper monographic and to have included redescriptions of all the species as well as descriptions of these additional species; but other pressing matters intervened and would have postponed the work for at least another year. It was not deemed advisable to withhold the generic rearrangement, and to this such descriptions of new species as were on hand have been added.

Fuller treatment of the family and figures of the generic characters I hope to publish in a not-far-distant future.

I am under much obligation to my learned friend, Mr. Edward Meyrick, of England, whose intimate knowledge of this family all over the world I have felt it my pleasant duty to consult freely, and who has untiringly responded in his usual liberal manner; also to Lord Walsingham and Mr. J. Hartley Durrant am I indebted for various helpful notes.

The genus Chambersia Riley, (Blepharocera Chambers, not Blanchard), which is included in the (Ecophoridæ in Doctor Dyar's List, is as yet unknown to me, and it is not possible from Chambers's description and figure definitely to place the genus before the species is rediscovered. I have omitted it from the present paper.

The genus Endrosis Hübner, which was placed in the family Elachistidæ in Doctor Dyar's List, following Meyrick's Handbook, and which Lord Walsingham and Rebel have included in the Blastobasidx, is in my judgment closely related to Borkhausenia Hübner, and is therefore included in this paper.

The American genera may be recognized by the following table:

1. Forewings with vein 7 to termen Forewings with vein 7 to costa or apex

. Second joint of labial palpi straight, porrected 2. Pleurota. Second joint of labial palpi curved

3. Forewings with vein 9 out of 7 Forewings with vein 9 separate

1. Martyringa.

4. Labial palpi with long tuft on second joint Labial palpi smooth or nearly so.

5. Hindwings with vein 5 nearest 6 Hindwings with vein 5 nearest 4 [?]

6. Veins 2 and 3 in forewings approximate 4. Eido. Veins 2 and 3 in forewings remote \%. Psilocorsis.

7. Hindwings with 6 and 7 diverging toward the tip Hindwings with 6 and 7 parallel throughout

5. Gerdana.

. Abdomen flattened 6. Cryptolechia.

Abdomen not flattened 
9. Forewings with veins 2 and 3 stalked 8. Agonopteryx. Forewings with veins 2 and 3 separate

9. Depressaria.

10. Hindwings with but 7 veins; 3 and 4 coincident 18. Endrosis.

Hindwings with all veins present

11. Hindwings with veins 3 and 4 separate

Hindwings with 3 and 4 connate or stalked

12. Forewings with 11 veins; 7 and 8 coincident

13. Decantha.

Forewings with 12 veins; 7 and 8 stalked

1\%. Euclemensia.

13. Forewings with 11 veins; 7 and 8 coincident 15. Fabiola.

Forewings with 12 veins; 7 and 8 stalked

14. Antennæ thickened with scales toward base 16. Ecophora.

Antennæ not thickened with scales

15. Hindwings with vein 5 connate or stalked with $3+4$

1\%. Triclonella. Hindwings with vein 5 free

16. Basal joint of antennæ with pecten

19. Borkhausenia.

Basal joint of antennæ without pecten

17. Hindwings with vein 5 nearest 6

Hindwings with vein 5 nearest 4

19

18. Hindwings with cross-vein between 7 and 8

20. Tamarrha. Hindwings with vein 8 free

21. Ethmia.

19. Forewings with 2 and 3 approximate or stalked

11. Semioscopis.

Forewings with 2 and 3 distant

20

20. Forewings obtuse; termen but slightly oblique

10. Inga.

Forewings pointed; termen oblique

12. Epicallima.

\section{Genus MARTYRINGA Busck.}

Mariyringa Busck, Jour. New York Ent. Soc., X, 1902, p. 96.

Antennæ stout, slightly serrate toward tip; basal joint without pecten. Labial palpi long, recurved; second joint somewhat thickened with scales, and rough beneath; terminal joint shorter. Forewings elongate, costa and dorsum nearly straight, apex and termen evenly rounded; 11 veins; one cubital vein absent; 2 and 3 coincident; 4 stalked with $2+3$ from the corner of the cell; 8 and 9 out of $7 ; 7$ to termen. Hindwings as broad as the forewings; 7 veins; 3 and 4 coincident; 4 and 5 connate; 6 and 7 parallel.

Type.-Martyringa latipennis (Walsingham).

Contains only the single species latipennis Walsingham, Dyar List N. Am. Lep., No. 5476; allied forms occur in China and Japan.

\section{Genus PLEUROTA Hübner.}

Pleurota HüBner, Verzeichniss bekannter Schmetterlinge, 1818, p. 406.

Labial palpi very long, porrected; second joint straight, densely clothed with long projecting scales throughout its entire length above and beneath; terminal joint short, slim, pointed. Antennæ finely ciliated, with pecten on basal joint. Tongue long, spirally coiled. Forewings elongate, pointed; termen very oblique; 12 veins; 7 and 8 stalked; 7 to termen. Hindwings as broad as forewings, ovate; cilia long; 8 veins; 6 and 7 parallel; 3 and 4 connate. 
Type.-Pleurota bicostella (Clerck).

Only the following species is at present recognized in North America. The genus is represented in Europe and Australia.

\section{PLEUROTA ALBASTRIGILELLA (Kearfott).}

Dorota albastrigilella Keanfott, Can. Entom., XXXIX, 1907, p. 8.

I have carefully examined Mr. Kearfott's unique type; it is a typical Fleurota, near to the European bicostella Clerck, and thus establishes the occurrence of this interesting genus in North America for the first time.

In the U. S. National Museum are specimens of this species from San Diego, California (W. S. Wright, collector).

The genus Dorata. Busck, which was tentatively referred to the CEcophoridæ on its erection, does not belong in this family, but will find its proper place in the Tineidæ.

The other species described by Mr. Kearfott as Dorota (Dorata) does not belong to this genus, differing both in venation and oral characters; medioliniella Kearfott is, however, truly allied to Dorata and may be temporarily retained in that genus, until additional material is forthcoming. At present it is known only through the unique type, which Mr. Kearfott kindly brought to Washington for my inspection.

\section{Genus EUMEYRICKIA Busck.}

Eumeyrickia Busck, Jour. New York Ent. Soc., X, 1902, p. 94.

Second joint of labial palpi with long projecting, pointed tuft; terminal joint erect, slender, acute, longer than second joint. Antennæ $\frac{2}{3}$; evenly ciliated throughout except on the basal joint, which is long, smooth without pecten. Forewings elongate, pointed; termen oblique; 12 veins; 7 and 8 stalked; 7 to termen just below apex; 2 from before angle of cell; 3,4 , and 5 equidistant. Hindwings ovate, nearly as broad as forewings; 8 veins; 6 and 7 parallel; 3 and 4 connate; 5 nearest 6 . Female with protruding horny ovipositor.

Type.-Eumeyrickia trimaculella (Fitch).

Only the one species is at present recognized.

\section{EUMEYRICKIA TRIMACULELLA (Fitch).}

Chœiochilus trimaculella Fitch, Rept. Nox. Ins., II, 1856, p. 233.

Ypsolophus trimaculellus Chavbers, Bull. U. S Geol. Surv., IV, 1878, p. 167.-Riley, Smith's List Lep. Bor. Am., 1891, No. 5532.

Anarsia ? albapulvella Chambers, Can. Entom., VII, 1875, p. 147.

Chimabache? haustellata Walsingham, Trans. Am. Ent. Soc., X, 1882, p. 173.-Riley, Smith's List Lep. Bor. Am., 1891, No. 5209.

Eumeyrickia trimaculella Busck, Jour. New York Ent. Soc., X, 1902, p. 94.Dyar, List. N. Am. Lep., 1903, No. 5843.

Antennæ blackish, each joint with a large white scale on the upper side. Labial palpi blackish fuscous, with apex of second joint and of 
the tuft white; terminal joint with two longitudinal white lines. Forewings blackish brown, sprinkled with scattered white scale, especially on apical third; three small yellowish costal spots, one on the middle of costal edge, a somewhat larger one at apical third and a third just before apex. Cilia alternately dark brown and yellowish white and with a black basal line along the edge of the wing. Hindwings dark fuscous.

\section{Alar expanse. -15 to $18 \mathrm{~mm}$.}

Habitat.-Northeastern United States; Canada.

The types of Fitch and Chambers are in the U. S. National Museum; topotypes of Lord Walsingham's species are also there; his type is in the collection of Professor Fernald.

I have included full references and description of this species so as to facilitate comparison with the unrecognized type of the following genus, which from description appears to be closely allied:

\section{Genus EIDO Chambers.}

Eido Chambers, Can. Entom., V, 1873, p. 72 ; Jour. Cinn. Soc. Nat. Hist., II, 1879 , p. 202, fig. 18 .

Venilia Chambers (not Duponchel), Can. Entom., III, 1872, p. 207.

\section{The following is Chambers's generic description:}

Terminal joint of the labial palpi as long as the second, slender, almost acicular. Tuft at the end of the second joint scarcely concealing the base of the third joint and pointing downward rather than forward. Antenne very slender, indistinctly pectinated, and microscopically pubescent, scarcely reaching the apical third of the wings.

Wings rather wide. Primaries ovate, lanceolate, faintly falcate beneath the tip. The costal attains the margin; the subcostal sends from before the middle a long branch to the costal margin and two other approximate branches from the end of the cell, from the first of which it bends down to its union with the discal vein, whence it proceeds toward the apex, before which it divides, sending one branch to the costal and one to the dorsal margin near the apex. Discal cell wide at the end. closed, the discal vein emitting two branches to the corsal margin; the median emits two branches before the end of the cell, from which it curves to the dorsal margin. Submedian furcate at base. Hindwings with the costal margin nearly straight, a little arched toward the base; costal vein straight, long, attaining the margin before the apex; subcostal very faint from the base to the distal vein, distinct from thence to the apex, straight; cell closed by a distinct discal vein, which sends two branches to the dorsal margin; median oblique, nearly straight, furcate at the end of the cell and with a branch to the dorsal margin before the end of the cell. Hind margin regularly curved, not emarginate; narrower than the forewings.

Type.-Eido albapalpella (Chambers).

This unusually detailed description, together with Chambers's figure of the venation, indicates that the genus belongs to the CEcophoridx and that it is very near if not identical with the foregoing genus Eumeyrickia. As, however, several small discrepancies occur, and 
as Chambers's descriptions and especially his figures are not always to be relied on, it would be unwise in the absence of any authentic material to unite the two genera on the present evidence, the more so because very small differences in structure will rightly differentiate genera in this family and because the specific descriptions clearly represent two different species.

I therefore leave the genus Eido as unrecognized at present, and the distinctive characters utilized in the generic table, being derived from description and figure alone, are tentative only, and may prove of no value on the discovery of the species, which should not be difficult.

\section{EIDO ALBAPALPELla (Chambers).}

Venilia albapalpella Chambers, Can. Entom., IV, 1872, p. 208.

Eido albapalpella Chambers, Can. Entom., V, 1873, p. 72 ; Jour. Cinn. Soc. Nat. Hist., II, 1879, p. 202, fig. 18-Dyar, List. N. Amer. Lep., 1903, No. 5502.

Eido albopalpella Riley, Smith's List. Lep. Bor. Am., 1891, No. 5543.

Apical joint of the palpi snowy white, with a narrow brown ring at the base; second joint white at its apex and on the inner surface; grayish brown on the outer surface. Antennæ grayish brown, annulate with white. Head, thorax, and primaries grayish brown with a row of yellowish ochreous spots around the apex of the wings at the base of the cilia.

Alar expanse. $-\frac{9}{16}$ inch; 14 to $15 \mathrm{~mm}$.

Captured in June in Kentucky.

The above is Chambers's description; no such insect is at present known to the writer, but it would seem easy to identify it, whenever found, by the striking form and color of the labial palpi.

\section{Genus GERDANA, new.}

Labial palpi rather short, not reaching vertex; second joint somewhat thickened with scales, which are slightly roughened underneath the tip; terminal joint shorter than second. Tongue long, scaled, curled. Antennæ a little longer than half the wing length, simple; basal joint with pecten. Forewing elongate, ovate, apex not acutely pointed, cell rather long; 12 veins; 7 and 8 stalked; 7 to termen; 3,4 , and 5 approximate from end of cell; 2 distant. Hindwings as broad as the forewings; costa excised from the middle; termen straight, oblique; dorsum straight, inner angle well developed; 8 veins; 6 and 7 parallel, but flaring towards the tip; 3 and 4 connate or stalked; 5 nearest 4 , cubital.

Type.-Gerdana caritella Busck.

Only one species is at present known.

\section{GERDANA CARITELLA, new species.}

Labial palpi deep saffron-yellow. Face, head, and thorax lighter yellow. Forewings light yellow, suffused with darker saffron-yellow;

Proc. N. M. vol. $\mathrm{xxxv-08-13}$ 
basal half of costal edge darkened with black dusting; on the middle of the cell is a blackish brown spot and obliquely below on the fold is a similar, but less prominent dark spot; at the end of the cell is a transverse, blackish brown spot, faintly connected with dark costal and dorsal spots above and below, so as to form an ill-defined and indistinct, narrow, transverse fascia at apical third of the wing; just before the tip of the wing is a more distinct, outwardly sharply angulated fascia of blackish dots, and the extreme tip is liberally dusted with black scales. Cilia light ochreous. The dark markings on the forewings are easily rubbed, so that only perfect specimens show all of the above ornamentation. Hindwings whitish fuscous; cilia ochreous. Abdomen ochreous. Legs ochreous, liberally dusted with black on the exposed sides.

Alar expanse. -13 to $14 \mathrm{~mm}$.

Habitat.-Plummers Island, Maryland, July (Busck); Kerrville, Texảs, April; Cohasset, Massachusetts, August (O. Bryant).

Type.-Cat. No. 11939, U.S.N.M.

A very pretty and easily recognized little moth with the ground color of Aristotelia natalella Busck and superficially resembling a Gelechiid.

\section{Genus CRYPTOLECHIA Zeller.}

Cryptolechia Zeller, Lep. Microp. Caffr., 1852, p. 106.

Machimia Clemens, Proc. Acad. Nat. Sci. Phila., 1S60, p. 211.

Labial palpi very long, tip of second joint reaching above vertex, slender; second joint somewhat thickened with smoothly appressed scales, which are but slightly roughened in front; terminal joint long, but decidedly shorter than second joint, slender, pointed. Antennæ without pecten on basal joint; in the males ciliated, in some species with very long ciliation; in the female simple. Tongue well developed. Forewings with 12 veins; 7 and 8 stalked; 7 to termen just below apex; vein 2 remote from vein 3 . Hindwings as broad as the forewings, with 8 veins; 3 and 4 connate; 5 nearest $4 ; 6$ and 7 parallel.

\section{Type.-Cryptolechia straminella Zeller.}

The genus is at present recognized from America, Africa, and Australia.

This genus is equal to and supersedes Machimia Clemens and the Australian genus Hoplitica ${ }^{a}$ Meyrick, of which about thirty Australian species are described. This latter synonymy was suggested to me and concurred in by Mr. Meyrick, who has kindly sent me several species of this genus in a large representative collection of Australian Microlepidoptera, and who has had American species from the writer. 
Some of the American species (concolorella, canariella, huachucella, ciliella) included by the writer in this genus have the ciliation of the male antennæ strikingly long (3 to 5), and Mr. Meyrick has utilized this character to separate closely allied Australian genera. All the American species referred to Cryptolechia by the writer have ciliated male antennæ, and I can only regard the different lengths of the cilia as degrees of the same character and not of sufficient value to separate the forms generically.

Mr. Meyrick himself would hardly insist upon the generic value of these differences, but he has repeatedly found it expedient to utilize them to break up otherwise excessively large groups in Australia. This reason does not exist in America, and I am glad to be able to disregard as a primary means of separation this and other secondary sexual characters, which in the writer's experience are excellent specific distinctions, but not indicative of well founded generic divisions.

To Cryptolechia I refer, besides the species described below, the following American species:

tentoriferella Clemens, Dyar List N. Am. Lep., No. 5853.

cretacea Zeller, Dyar List N. Am. Lep., No. 5846.

obscuromaculella Chambers, Dyar List N. Am. Lep., No. 5848.

concolorella Beutenmüller, Dyar List N. Am. Lep., No. 5845.

CRYPTOLECHIA CANARIELLA, new species.

Labial palpi very long, reaching far above the vertex; light yellow, sprinkled with darker reddish yellow exteriorly. Tongue yellowish white. Antennæ yellowish with white annulations; in the female simple, in the male with very long (5) ciliation on the underside. Face, head, and thorax light canary-yellow. Forewings uniformly light canary-yellow, the color only slightly deeper yellow at base of costa. Cilia whitish yellow. Hindwings semitransparent, light whitish yellow. Abdomen yellow. Legs light canary-yellow, mottled exteriorly with darker ochreous.

Alar expanse.-24 to $25 \mathrm{~mm}$.

Habitat.-Huachuca Mountains, Arizona.

Type.-Cat. No. 11940, U.S.N.M. Cotype in collection of Mr. W. D. Kearfott, to whom I am under obligation for this and other interesting species.

A large striking canary-yellow species not mistakable for any described American species.

\section{CRYPTOLECHIA HUACHUCELLA, new species.}

Labial palpi whitish with brownish base and touched exteriorly with rose-red; terminal joint with a dark-brown annulation around 
VOL. $\times \times \times V$.

the base and a narrow black longitudinal line in front. Antennæ in male strongly ciliated on the underside (4). Face ochreous white. Head and thorax salmon-colored. Forewings salmon-ochraceous, unicolored. Cilia ochreous. Hindwings light ochreous fuscous; cilia ochreous. Abdomen ochreous. Legs light ochreous; tarsal joints slightly dark-mottled.

Alar expanse. -22 to $23 \mathrm{~mm}$.

Habitat.-Huachuca Mountains, Arizona.

Type.-Cat. No. 11941, U.S.N.M. Cotype in Mr. Kearfott's collection.

Closely allied to the foregoing species and equally striking in color. The ciliation of the antennæ in the male is hardly as long as in canariella.

CRYPTOLECHIA CILIELLA, new species.

Labial palpi light ochreous with base of second joint black. Antennæ blackish, in male with long (3) cilia on the underside. Face, head, and thorax light dirty ochreous. Forewings light ochreous, finely dusted with fuscous, especially toward apex; first and second discal spot blackish brown; at apical third is an undulating, outwardly curved row of small blackish dots. Cilia dirty ochreous. Hindwings dark fuscous. Abdomen ochreous fuscous. Legs light ochreous; tarsal joints sprinkled with fuscous.

Alar expanse. $-19 \mathrm{~mm}$.

Habitat.-Baboquivari Mountains, Pima County, Arizona, July (O. C. Poling, collector).

Type.-Cat. No. 11942, U.S.N.M. Cotype in the collection of Mr. W. D. Kearfott, from whom the specimens were received.

A plain species, very similar to the type of the genus, but smaller and with much longer ciliation of the male antennæ. In this it approaches concolorella Beutenmüller, as well as in color; but this species is a more loosely scaled insect with more rounded wings.

\section{Genus PSILOCORSIS Clemens.}

Psilocorsis Clemens, Proc. Acad. Nat. Sci. Phila., 1860, p. 213.

Labial palpi very long and slender, smooth; second joint hardly thickened with appressed scales; terminal joint nearly as long as second joint. Antenna simple in both sexes, without pecten on basal joint. Tongue developed, scaled, spiraled. Forewings with rather squarely cut termen; 12 veins; 7 and 8 stalked; 7 to termen; 2 approximate to 3 . Hindwings nearly as broad-as the forewings; 8 veins; 6 and 7 parallel; 3 and 4 connate; 5 nearest 4 , cubital.

Type.-Psilocorsis quercicella Clemens.

The genus is at present recognized only from America. 
I have but little to add to my remarks on the species of this genus, ${ }^{a}$ and $\mathrm{I}$ include the following distinct species:

quercicella Clemens, Dyar List N. Am. Lep., No. 5851.

obsoletella Zeller, Dyar List N. Am. Lep., No. 5849.

ferruginosa Zeller, Dyar List N. Am. Lep., No. 5847.

faginella Chambers, Dyar List N. Am. Lep., No. 5847, part.

cryptolechiella Chambers, Dyar List N. Am. Lep., No. 5847, part.

dubitatella Zeller, Dyar List N. Am. Lep., No. 5847, part.

reflexella Clemens, Dyar List N. Am. Lep., No. 5848.

With cressonella Chambers, Dyar List N. Am. Lep., No. 5847, part; a synonym.

The larva, described as that of Cryptolechia quercicella by Mr. Arthur Gibson ${ }^{b}$ feeding on Populus, does not belong to that species, the larva of which feeds on oak and is well described by Clemens. Mr. Gibson's moth is an undescribed species of Psilocorsis.

Besides the species now disposed of in the genera Cryptolechia and Psilocorsis, and sparsicitiella Clemens, which is made type of a new genus in the following pages, only one species, included in Cryptolechia in Dyar's List, remains, namely, piperatella Zeller (Dyar's List, No. 5850), which does not belong to the present family at all, but to the Gelechiidæ, and for which I make the following new genus:

\section{Genus DURRANTIA, new (Gelechiidæ).}

Labial palpi long, curved; second joint slightly thickened with smoothly appressed scales; terminal joint long, but shorter than second, acute. Tongue well developed, spiraled. Maxillary palpi small, simple. Antennæ somewhat more than half the wing length, in the female simple, in the male finely serrate and pubescent. Forewings elongate ovate, apex bluntly pointed; termen rounded; 12 veins; 7 and 8 stalked (or coincident), both to costa; 3,4 , and 5 approximate at the end of the cell; 2 from outer fifth of cell; $1^{b}$ furcate at base. Hindwings as broad as the forewings; costa nearly straight; apex blunt; termen and dorsum evenly rounded; 8 veins; 3 and 4 stalked; 5 cubital, approximate to 3 and $4 ; 6$ and 7 stalked; 8 free; cell wide; discal vein very oblique. Posterior tibiæ thickly clothed with rough hairs. The female with protruding horny and hairy ovipositor.

\section{Type.-Durrantia piperatella (Zeller).}

The type has veins 7 and 8 in forewings stalked; I include as generic character "or coincident" in order not to exclude another closely related and very similar, undescribed Texan species, which I believe congeneric, in spite of this single difference.

The genus is named in honor of my friend and co-worker, John Hartley Durrant, to whom I am under pleasant obligations through

\footnotetext{
${ }^{a}$ Proc. Ent. Soc. Washington, V, 1903, p. 207.

${ }^{b}$ Can. Entom., XL, 1908, p. 84.
} 
many years for much valuable assistance and advice, and together with whom I studied and discussed the present genus at Merton Hall three years ago.

\section{Genus AGONOPTERYX Hübner.}

Agonopteryx HüвnER, Verzeichniss bekannter Schmetterlinge, 1818, p. 410.

Labial palpi long, curved; second joint with well-developed, furrowed brush on the underside; terminal joint slender, acute, shorter than second joint. Antennæ simple in both sexes, with pecten on basal joint. Tongue developed, scaled at base. Forewings elongate; apex usually obtuse; termen rounded; 12 veins; 7 and 8 stalked, both to costal edge; 2 and 3 stalked. Hindwings as wide or wider than the forewings, with costa nearly straight, termen evenly rounded: inner angle strongly developed, so as to cause a sinuation in the dorsal edge; 8 veins; 6 and 7 parallel; 3 and 4 connate or short-stalked; 5 cubital, approximate to 4 . Abdomen flattened.

Type.-Agonopteryx ocellana (Fabricius).

This genus comprises Meyrick's section A of Depressaria, which differs from section $B$ in having veins 2 and 3 in the forewings stalked. Through the kindness of Mr. Durrant I have lately received advance proofs of parts of Lord Walsingham's paper in Proceedings of the Zoological Society of London for 1907, from page 955 of which I learn that he has adopted Wallengren's idea of separate genera for the two groups, which indeed seems logical.

The described American species, which are referable to this genus, are:

atrodorsella Clemens, Dyar List N. Am. Lep., No. 5854.

umbraticostella Walsingham, Dyar List N. Am. Lep., No. 5855.

thoracenigraeela Chambers, Dyar List N. Am. Lep., No. 5856.

gracilis Walsingham, Dyar List N. Am. Lep., No. 5857.

canella Busck, Proc. U. S. Nat. Mus., XXVII, 1904, p. 764.

nebulosa Zeller, Dyar List N. Am. Lep., No. 5870.

scabella Zeller, Dyar List N. Am. Lep., No. 5892.

ciniflonella Zeller, Dyar List N. Am. Lep., No. 5869.

Klamathiana Walsingham, Dyar List N. Am Lep., No. 5868.

psoraliella Walsingham, Dyar List N. Am. Lep., No. 5865.

walsinghamiella Busck, Dyar List N. Am. Lep., No. 5864.

nigrinotella Busck, Proc. Ent. Soc. Washington, IX, 1908, p. 88.

curviliniella Beutenmüller, Dyar List N. Am. Lep., No. 5874.

amyrisella Busck, Dyar List N. Am. Lep., No. 5872.

clemensella Chambers, Dyar List N. Am. Lep., No. 5862.

rosaciliella Busck, Dyar List N. Am. Lep., No. 5863.

pulvipennella Clemens, Dyar List N. Am. Lep., No. 5858.

gelidella Busck, Proc. Ent. Soc. Washington, IX, 1908, p. 90.

thoracefasciella Chambers, Dyar List N. Am. Lep., No. 5867.

arnicella Walsingham, Dyar List. N. Am. Lep., No. 5859.

fulva Walsingham, Dyar List N. Am. Lep., No. 5871.

novimundi Walsingham, Dyar List N. Am. Lep., No. 5866. 
muricolorella Busck, Dyar List N. Am. Lep., No. 5873. sanguinella Busck, Dyar List N. Am. Lep., No., 5861. argillacea Walsingham, Dyar List N. Am. Lep., No. 5860. amissella Busck, Proc. Ent. Soc. Washington, IX, 1908, p. 89. pallidella Busck, Proc. U. S. Nat. Mus., XXVII, 1904, p. 765. pergandeella Busck, Proc. Ent. Soc. Washington, IX, 1908, p. 89. flavicomella Engel, Ent. News, XVIII, 1907, p. 276. senecionella Busck, Dyar List N. Am. Lep., No. 5875. sabulella Walsingham, Dyar List N. Am. Lep., No. 5876. arenella Schiffermüller, Dyar List N. Am. Lep., No. 5877. canadensis Busck, Dyar List N. Am. Lep., No. 5878. lythrella Walsingham, Dyar List N. Am. Lep., No. 5879. posticella Walsingham, Dyar List N. Am. Lep., No. 5880. nubiferella Walsingham, Dyar List N. Am. Lep., No. 5881. robiniella Packard, Dyar List N. Am. Lep., No. 5882. lecontella Clemens, Dyar List N. Am. Lep., No. 5883.

AGONOPTERYX PLUMMERELLA, new species.

Second joint of labial palpi slim and smooth on basal half; with short trumpet-formed brush on outer half; light ochreous gray, externally speckled with dark fuscous; terminal joint rather thick; light ochreous gray, strongly mottled with black scales, which congregate into an ill-defined basal spot and a broad annulation before the tip. Antennæ dark fuscous with narrow black annulations. Face light ochreous gray. Head and thorax dark ochreous fuscous, mottled with darker fuscous. Forewings pepper-and-salt colored; under a lens with the ochreous fuscous ground color thickly mottled with white and black scales; no lighter basal patch; a round white second discal dot is preceded by a few black scales and easily overlooked; along the costal edge is a series of small ill-defined black spots, separated by white and ochreous scales. Cilia ochreous fuscous. Hindwings shining fuscous, whitish on basal half and darker toward the tip. Abdomen light ochreous fuscous. Legs ochreous; tarsal joints mottled with black.

Alar expanse. $-24 \mathrm{~mm}$.

Habitat.-Plummers Island, Maryland (Busck) ; Cincinnati, Ohio (Miss A. F. Braun).

Type.-Cat. No. 11943, U.S.N.M.

Very near to nebulosa Zeller, but considerably larger and with base of the hindwings more whitish.

AGONOPTERYX SCABELLA (Zeller).

Epeleustia scabella Zeller, Dyar List. N. Am. Lep., No. 5892.

Not being acquainted with this species in nature at the time of my review of the genus Depressaria, ${ }^{a}$ I concluded from Zeller's descrip- 
tion that if the species belonged to the group at all it would have veins 2 and 3 separate, and it was placed accordingly in Doctor Dyar's list. My friend Mr. Durrant kindly corrected me in this and I have since had the opportunity of examining Zeller's unique type in Lord Walsingham's collection at Merton Hall, England. The species is an Agonopteryx, having veins 2 and 3 in the forewings stalked, and there is nothing very remarkable about it, aside from the small tufts of raised scales on the forewings. I agree with Mr. Durrant in placing it next to nebulosa Zeller, which it much resembles.

\section{Genus DEPRESSARIA Haworth.}

Depressaria Hawonth, Lep. Brit., 1812, p. 505.

This genus has the same characters as the foregoing, from which it differs only in veins 2 and 3 being separate instead of stalked in the forewings. The color pattern of the forewing is normally characteristic enough to readily indicate to which of the two genera a species belongs.

The described American species belonging to this genus are the following:

alienella Busck, Dyar List N. Am. Lep., No. 5884.

togata Walsingham, Dyar List N. Am. Lep., No. 5885.

juliella Busck, Proc. Ent. Soc. Washington, IX, 1908, p. 91.

? apiella Hübner, nervosa Haworth, Dyar List N. Am. Lep., No. 5887.

barberella Busck, Dyar List N. Am. Lep., No. 5888.

heractiana De Geer, Dyar List N. Am. Lep., No. 5889.

betulella Busck, Dyar List N. Am. Lep., No. 5886.

groteella Robinson, Dyar List N. Am. Lep., No. 5890.

maculatella Busck, Proc. Ent. Soc. Washington, IX, 1908, p. 90.

cinereocostella Clemens, Dyar List N. Am. Lep., No. 5891.

\section{Genus INGA, new.}

Labial palpi long, curved; second joint thickened with smoothly appressed scales, slightly roughened in front; terminal joint long, slender, acute, shorter than second joint. Tongue long, spiraled. Antennæ without pecten on basal joint, simple in both sexes. Forewings with apex blunt, termen oblique; 12 veins; 7 and 8 stalked, both to the costal edge. Hindwings as broad as the forewing; 8 veins; 6 and 7 parallel; 3 and 4 connate; 5 cubital, approximate to 4 . Female with protruding horny and hairy ovipositor.

Type.-Inga sparsiciliella (Clemens).

Closely related to Agonopteryx, differing mainly in the absence of pecten on basal joint of the antennæ and by the abdomen not being depressed.

Only the one species is at present recognized. 
INGA SPARSICILIELLA (Clemens).

Cryptolechia sparsiciliella (Clemens), Dyar List. N. Am. Lep., No. 5844.

11. Genus SEMIOSCOPIS Hübner.'

Semioscopis HüBner, Verzeichniss bekannter Schmetterlinge, 1818, p. 402.

Labial palpi moderately long, curved; second joint with appressed scales, which protrude somewhat at apex; terminal joint shorter than second joint. Antennæ without pecten on basal joint, shortly ciliated in the male, simple in the female. Tongue developed, though rather short. Forewings ample, elongate; apex blunt, termen very oblique; 12 veins; 7 and 8 stalked; 7 to costa or apex; 2 and 3 stalked or approximated. Hindwings as broad as forewings, ovate; 8 veins; 7 and 6 parallel; 3 and 4 connate or closely approximated; 5 cubital, nearest 4 .

Type.-Semioscopis steinkellneriana (Schiffermiiller).

The genus is also represented in Europe.

The following American species belonging to this genus are at present described:

packardella Clemens, Dyar List Lep. N. Am., No. 5893.

merriccella Dyar, Can. Entom., XXXIV, 1902, p. 319.

aurorella Dyar, Can. Entom., XXXIV, 1902, p. 319.

megamicrella Dyar, Can. Entom., XXXIV, 1902, p. 320.

inornatella Walsingham, Dyar List N. Am. Lep., No. 5895.

allenella Walsingham, Dyar List N. Am. Lep., No. 5894.

\section{Genus EPICALLiMA Dyar.}

Epicallima Dyar, Bull. U. S. Nat. Mus., No. 52, 1903, p. 525.

Labial palpi very long, recurved; second joint slightly thickened with smoothly appressed seales; terminal joint long, slender, but shorter than second joint. Antennæ without pecten on basal joint, simple, slightly serrated toward the tip in the males. Tongue developed. Forewings rather narrow, pointed, termen oblique; 12 veins; 7 and 8 stalked, both to costa. Hindwings not as broad as the forewings; 8 veins, 6 and 7 parallel $; 3$ and 4 connate; 5 distant but cubital.

Type.-Epicallima argenticinctella (Clemens).

The genus is widely distributed. The following European species, hitherto placed in the genus Borkhausenia, are referable to Epicallima: procerella Schiffermïller; schafferella Linnæus; grandis Desvignes; augustella Hübner; Tuctuosella Duponchel; strcmella Fabricius; tripuncta Haworth, and rhatica Frey; probably also other intervening species, with which I am not familiar.

The following American species belong in the genus:

argenticinctella Clemens, Dyar List N. Am. Lep., No. 5920.

edithella Busck Jour. New York Ent. Soc., XV, 1907, p. 138. 
coloradella Walsingham, Dyar List N. Am. Lep., No. 5923. dimidiella Walsingham, Dyar List N. Am. Lep., No. 5925.

quadrimaculella Chambers, Dyar List N. Am. Lep., No. 5927.

13. Genus DECANTHA, new.

Labial palpi moderately long; second joint somewhat thickened with appressed scales, slightly rough in front; terminal joint shorter than second joint, rather thick, pointed. Antennæ with strong pecten on basal joint; simple. Tongue developed. Forewings elongate, pointed; termen very oblique; 11 veins; 7 and 8 coincident to costal edge. Hindwings narrower than the forewings; 8 veins; 6 and 7 parallel; 3 and 4 separate; 5 nearest 4 , cubital.

Type.-Decantha borkhausenii (Zeller).

Includes only the one species, common to Europe and North America :

borkhausenii Zeller, Dyar List N. Am. Lep., No. 5922, with boreasella Chambers, Dyar List N. Am. Lep., No. 5921, as a synonym.

\section{Genus EUCLEMENSIA Grote.}

Euclemensia Grote, Can. Entom., X, 1878, p. 69.

Labial palpi long, slender, curved, smooth; terminal joint shorter than second joint. Antennæ somewhat thickened with scales, without pecten on basal joint. Tongue obsolete. Forewing narrow, elongate, pointed; 12 veins; 7 and 8 stalked; both to costa. Hindwings nearly as broad as forewings; 8 veins; 6 and 7 parallel; 3 and 4 separate.

Type.-Euclemensia bassettella (Clemens).

An American genus, not identified elsewhere; the two species known are parasitic on Kermes.

bassettella Clemèns, Dyar List N. Am. Lep., No. 5918.

schwarziella Busck, Dyar List N. Am. Lep., No. 5919.

\section{Genus FABIOLA, new}

Labial palpi long, curved; second joint with smoothly appressed scales; terminal joint slender, nearly as long as second joint. Antennæ without pecten on basal joint; in the male with rather long (2) cilia. Tongue developed. Forewings elongate, ovate, abtusely pointed; 11 veins; 7 and 8 coincident to costal edge. Hindwings narrower than the forewings; 8 veins; 6 and 7 parallel; 3 and 4 connate.

Type.-Fabiola shalleriella (Chambers).

The European pokornyi Nickerl belongs to this genus.

Only the one North American species is at present known:

shalleriella Chambers, Dyar List N. Am. Lep., No. 5928.

16. Genus ECOPHORA Latreille.

Ecophora Latreille, Gen. Crust. et Insect., 1806.

Labial palpi long, curved; second joint thickened with appressed scales; terminal joint shorter than second. Tongue developed. An- 
tennæ without pecten on basal joint; thickened with rough scales on basal half; in the males strongly ciliated. Forewings with 12 veins; 7 and 8 stalked; both to costal edge. Hindwings nearly as broad as the forewings; 8 veins; 6 and 7 parallel; 3 and 4 connate or stalked.

Type.-Ecophora sulphurella (Fabricius).

The genus consists of a few European and the following North American species:

newmanella Clemens, Dyar List N. Am. Lep., No. 5932.

\section{Genus TRICLONELLA Busek.}

Labial palpi long, smooth, recurved; second joint somewhat thickened with smoothly appressed scales; terminal joint long, slender but shorter than second joint. Antennæ with pecten on basal joint, simple, slightly serrate and ciliate in the male. Tongue long, spiraled. Forewings elongate, ovate, obtusely pointed; 12 veins; 7 and 8 stalked, both to costa. Hindwings narrower than the forewings; 8 veins; 6 and 7 parallel; 3 and 4 connate or stalked; 5 connate with or stalked from 4.

Type.-Triclonella pergandeella Busck.

A small American genus with a peculiar Australian aspect, not yet satisfactorily recognized from elsewhere.

Villella Busck (Dyar List N. Am. Lep., No. 5917), described under this genus, is a Blastobasid belonging to the genus Holcocera Clemens.

The following are the North American species referable to this genus :

pergandeella Busck, Dyar List N. Am. Lep., No. 5916.

determinatella Zeller, Dyar List N. Am. Lep., No. 5924.

18. Genus ENDROSIS Hübner.

Labial palpi moderately long, curved, smooth; second joint somewhat thickened with appressed scales; terminal joint nearly as long as second. Antennæ with pecten on basal joint; in the males slightly serrated toward tip and ciliated. Tongue developed. Forewings elongate, pointed, with 12 veins; 7 and 8 stalked both to costal edge. Hindwings not as broad as the forewings; 7 veins; 6 and 7 parallel; 3 and 4 coincident; 5 connate or short-stalked with 4 .

Type.-Endrosis lacteella (Schiffermüller).

The genus contains only the one semidomestic, widely distributed species :

lacteella Schiffermüller, Dyar List N. Am. Lep., No. 6170.

19. Genus BORKHAUSENIA Hübner.

Borïausenia HüBNER, Verzeichniss bekannter Schmetterlinge, 1818, p. 420.

Labial palpi moderately long, curved; second joint somewhat thickened and roughened beneath with scales; terminal joint shorter than 
second. Tongue developed. Antennæ with pecten on basal joint; ciliated in the males. Forewings elongated, pointed; 12 veins; 7 and 8 stalked both to costa. Hindwings narrower or nearly as broad as the forewings; 8 veins; 7 and 6 parallel; 3 and 4 connate.

Type.-Borkhausenia minutella (Linnæus).

A large, widely distributed genus; the larvæ feed on dry vegetable matter.

The species placed under this genus (Ecophora Authors) in Doctor Dyar's list have mostly been disposed of under Epicallima, Fabiola and Decantha in the foregoing.

Thoracella Walsingham (Dyar's List, No. 5929) is a Gelechiid and a synonym of Epithectis bicostomaculella Chambers, as examination of the type proves.

Constrictella Zeller (Dyar's List, No. 5930) is a Theisoa, and is repeated under No. 6130.

Ascriptella Busck (Can. Entom., June, 1908) belongs, according to Mr. Meyrick, in his Australian genus Crossophora, which differs from Borkhausenia only in the longer male antennal ciliation. As the other species of Borkhausenia have similar ciliated antennæ, only in less degree, I prefer to retain the species in the genus as described.

The four Californian species described by Lord Walsingham ${ }^{a}$ were placed by an oversight under the Blastobasid genus Hypatopa Walsingham, but cotypes of the first three species, generously presented to the U. S. National Museum by his lordship, prove them to belong to the present genus, and Mr. Durrant has kindly informed me that orites Walsingham is congeneric with the three others.

The following North American species, then, belong in Borkhausenia:

pseudospretella Stainton, Dyar List N. Am. Lep., No. 5926.

ascriptella Busck, Can. Entom., XL, June, 1908.

episcia Walsingham, Proc. U. S. Nat. Mus., XXXIII, 1907, p. 211.

conia Walsingham, Proc. U. S. Nat. Mus., XXXIII, 1907, p. 212.

fasciata Walsingham, Proc. U. S. Nat. Mus., XXXIII, 1907, p. 213.

orites Walsingham, Proc. U. S. Nat. Mus., XXXIII, 1907, p. 213.

\section{Genus TAMARRHA Walker.}

Tamarrha WaLker Cat. Lep. Het. Br. Mus., XXIX, 1864, p. 816.

Labial palpi slender, smooth, curved; terminal joint shorter than second. Antennæ without pecten on basal joint, simple in both sexes. Tongue developed. Forewings elongate, apex blunt; 12 veins; 7 and 8 stalked to costa; rest separate. Hindwings as broad as the forewings, elongate-ovate; 8 veins; vein 8 is connected at the end of the cell with vein 7 by an oblique cross vein, and basal part of 
7 is obsolete; veins 6 and 7 parallel; 5 radial, nearest to $6 ; 3$ and 4 connate.

\section{Type.-Tamarrha niveosella Walker.}

The genus Babaiaxa Busck (type, delliella Fernald) is a synonym of Tamarrha, as shown by the writer. ${ }^{a}$

My friend Mr. Meyrick has all along contended that the peculiar aberrant structure of the venation in the hindwing is of slight importance generically and he considers the present genus synonymous with Ethmia. Having found a similar cross-vein in the males of some of the South American Stenomidæ, where it is plainly the normal subcostal cross-vein, found in the family Gelechiidæ, connecting veins 7 and 8 , which has been pushed outwards in order to strengthen the costal region, which is widened on account of a large hair pencil, I am inclined to accept Mr. Meyrick's view, the more so as some apparently typical species of the genus Ethmia (hilarella Zeller, funerella Fabricius) possess a similar cross-vein. This vein is thus to be explained as the persisting cross-vein, modified on account of a hair tuft, which itself may not have persisted. In this connection it is significant that the type of Tamarrha and some other species of the genus have a costal tuft on the hindwings.

There is, however, no difficulty in the North American fauna in keeping the genus Tamarrha distinct from Ethmia, and I prefer to do so for the present.

The presence of the cross-vein mentioned above, together with the relationship of vein 5 of the hindwings to the radial system of the neuration, indicates that further study of these two genera, on which I am now engaged at Merton Hall, may justify the erection of a new family for their reception.

The following North American species are referable to this genus:

delliella Fernald, Dyar List N. Am. Lep., No. 5935.

bittenella Busck, Proc. U. S. Nat. Mus., XXX, 1906, p. 730.

TAMARRHA DELLIELLA (Fernald).

I am glad to be able to record the food plant of this beautiful species. It was bred by Mr. J. D. Mitchell at Victoria, Texas, from Ehretia elliptica de Candolle. Adult issued August 7, 1907.

The food plant belongs to the family Boraginaceæ, to which the genus Ethmia is normally partial.

\section{Genus ETHMiA Hübner.}

Ethmia HüBNER, Verzeichniss bekannter Schmetterlinge, 1818, p. 163.

Labial palpi moderately long, second joint thickened with smoothly appressed scales or with a more or less developed rough tuft; ter- 
minal joint shorter than second. Antennæ without pecten on basal joint; shortly ciliated in the males; simple in the females. Tongue developed. Forewings elongate, with obtuse apex and rather oblique termen; 12 veins; 7 and 8 stalked to costal edge; rest separate. Hindwings as broad as the forewings; 8 veins; 8 free; 6 and 7 parallel; 3 and 4 connate; 5 radial, approximate to 6 .

T'ype.-Ethmia aurifluella Hübner.

A widely distributed genus.

The following North American species are referable to this genus:

albistrigella Walsingham, Dyar List N. Am. Lep., No. 5897.

umbramarginella Busck, Proc. Ent. Soe. Washington, VIII, 1907, p. 94.

coquillettella Busck, Proc. Ent. Soc. Washington, VIII, 1907, p. 95.

lassenella Busck, Proc. Ent. Soc. Washington, IX, 1908, p. 92.

albitogata Walsingham, Proc. U. S. Nat. Mus., XXXIII, 1907, p. 199.

monticola Walsingham, Dyar List N. Am. Lep., No. 5905.

fuscipedella Walsingham, Dyar List N. Am. Lep., No. 5914.

caliginosella Busck, Jour. New York Ent. Soc., XII. 1904, p. 44.

arctostaphylella Walsingham, Dyar List N. Am. Lep., No. 5898.

obscurella Beutenmüller, Dyar List N. Am. Lep., No. 5906.

macelhosiella Busck, Proc. Ent. Soc. Washington, VIII, 1907, p. 93.

mirusella Chambers, Dyar List N. Am. Lep., No. 5904.

discostrigella Chambers, Dyar List N. Am. Lep., No. 5899.

semitenebrella Dyar, Jour. New York Ent. Soc., X, 1902, p. 204.

subcœrulea Walsingham, Dyar List N. Am. Lep., No. 5900.

confusella Walker, Dyar List N. Am. Lep., No. 5915.

josephinella Dyar, Jour. New York Ent. Soc., X, 1902, p. 205.

marmorea Walsingham, Dyar List N. Am. Lep., No. 5903.

semilugens Zeller, Dyar List N. Am. Lep., No. 5907.

trifurcella Chambers, Dyar List N. Am. Lep., No. 5911.

semiombra Dyar, Jour. New York Ent. Soc., 1902, p. 206.

hagenella Chambers, Dyar List N. Am. Lep., No. 5901.

apicipunctella Chambers, Dyar List N. Am. Lep., No. 5902.

longimaculella Chambers, Dyar List N. Am. Lep., No. 5912.

coranella Dyar, Jour. New York Ent. Soc., X, 1902, p. 207.

zelleriella Chambers, Dyar List N. Am. Lep., No. 5913.

Including the synonymy as worked out by Doctor Dyar, ${ }^{a}$ which I am pleased to adopt in full, with the exception noted below, the above list accounts for all North American species referred to this genus except the names under No. 5910 of Doctor Dyar's list, which have been the cause of some misconception in the past. Chambers's Anesychia texanella ${ }^{b}$ was naturally placed in the genus Ethmia (Psecadia) by Lord Walsingham ${ }^{c}$ on the evidence of Chambers's description and generic name, and it has been retained in this genus since; but Chambers himself expressed a doubt, and his unquestionably authentic type in the Museum of Comparative Zoology in Cambridge proves it to be a large Gelechia species near barnesiella Busck.

\footnotetext{
${ }^{a}$ Jour. New York Ent. Soc., V, 1902, pp. 202-208.

${ }^{b}$ Jour. Cinn. Soc. Nat. Hist., II, 1880, p. 179.

${ }^{c}$ Insect Life, I, 1888, p. 149.
} 
Through a mistake of the paging, Doctor Dyar supposed that this texanella Chambers was preoccupied by Ethmia texanella (zelleriella Chambers), and gave it in his list the new name chambersella, which thus was unnecessary and becomes a synonym of Gelechia (Anesychia) texanella Chambers. But on discovering his mistake as to the paging and after correcting it, ${ }^{a}$ Doctor Dyar continued :

I have a single specimen without label, which I attribute to this species, but which may possibly not be the same. If not, the name chambersella can be used for it.

And he then gives a description of it and a type number in the U.S. National Museum.

This latter chambersella Dyar is neither an Ethmia nor Gelechia (Anesychia) texanella Chambers, but is a Gelechiid, referable to the genus Durrantia Busck. The name thus being preoccupied, it may be known as Durrantia obiterella, new name, with the synonym Ethmia chambersella Dyar (not Dyar), and the type is Cat. No. 6625, U.S.N.M.

${ }^{a}$ Jour. New York Ent. Soc., X, 1902, p. 208. 


\section{$2 \mathrm{BHL}$ Biodiversity Heritage Library}

Busck, August. 1904. "A GENERIC REVISION OF AMERICAN MOTHS OF THE FAMILY CECOPHORIDAE, WITH DESCRIPTIONS OF NEW SPECIES." Proceedings of the United States National Museum 35, 187-207. https://doi.org/10.5479/si.00963801.35-1644.187.

View This Item Online: https://www.biodiversitylibrary.org/item/32327

DOI: https://doi.org/10.5479/si.00963801.35-1644.187

Permalink: https://www.biodiversitylibrary.org/partpdf/27580

\section{Holding Institution}

Smithsonian Libraries

\section{Sponsored by}

Smithsonian

\section{Copyright \& Reuse}

Copyright Status: NOT_IN_COPYRIGHT

This document was created from content at the Biodiversity Heritage Library, the world's largest open access digital library for biodiversity literature and archives. Visit BHL at https://www.biodiversitylibrary.org. 